\title{
Revisiting the "Transnational" in Migration Studies: A Sociological Understanding
}

Revisiter le "transnational » dans les études sur les migrations: une conception sociologique

El «transnacional» en los estudios migratorios: sociológicos bases

Il "transnazionale" nello studio delle migrazioni: una rivisitazione sociologica

\section{Paolo Boccagni}

\section{(c) OpenEdition}

Journals

\section{Electronic version}

URL: https://journals.openedition.org/remi/5744

DOI: $10.4000 /$ remi.5744

ISSN: $1777-5418$

Publisher

Université de Poitiers

\section{Printed version}

Date of publication: 1 March 2012

Number of pages: $33-50$

ISBN: 979-10-90426-03-0

ISSN: 0765-0752

\section{Electronic reference}

Paolo Boccagni, "Revisiting the "Transnational" in Migration Studies: A Sociological Understanding", Revue européenne des migrations internationales [Online], vol. 28 - $n^{\circ} 1$ | 2012, Online since 01 March 2015, connection on 14 April 2022. URL: http://journals.openedition.org/remi/5744 ; DOI: https:// doi.org/10.4000/remi.5744 


\title{
Revisiting the "Transnational" in Migration Studies: A Sociological Understanding
}

\author{
Paolo BOCCAGNI ${ }^{1}$
}

\section{INTRODUCTION}

$\mathrm{M}$ igrant transnationalism, understood as a social phenomenon or as an optic for studying the phenomenon itself, has been the subject of an ever increasing and diverse literature in the last decades. Despite the huge amount of empirical research on migrants' transnational participation, and the number of theoretical elaborations about it, this academic field is however still deeply divided. There is limited communication between those scholars who would identify themselves with an almost principled transnational perspective, and those who are much more cautious, or openly critical, about it. Even so, both sides would probably agree on the room that still exists, in a way or another, for further elaboration on migrant cross-border participation and on its sociological bases.

Following this exploratory stance, in this article I will propose a sociological revisit of some questions still unsettled in transnational migration studies, expanding on my previous contributions on the topic (Boccagni, 2010; 2012a; 2012b). Building on an everyday-level, actor-centered understanding of migrant transnationalism, I will argue for the opportunity to go over the state-of-the-art debate along four lines of critical investigation:

- The necessity of further attempts to define the transnational in empirically relevant terms, despite the limits inherent in any definition;

- The nexus, often taken for granted and yet not so obvious, between the conceptual tools of a transnational perspective and those available in the broader realm of migration studies; - The need to investigate further the biographical and life course-related bases of migrant transnational practices; 
- The difference that a greater investment in reflexivity would make, again, for a better understanding of migrants' transnational ties and relationships.

After raising these points, I will briefly contend that a transnational optic, once critically revisited, has still much to say in migration studies, and beyond.

\section{DEFINING THE TRANSNATIONAL: A CRITICAL AND AMBIVALENT TASK}

Raising some cautionary notes on the power and limitations of definitions may seem surprising, after over two decades (and uncountable books and papers) in which transnational migration has been studied and discussed in every respect. ${ }^{2}$ Yet, the significance of the issues this notion deals with may not be enough to explain its academic success story. Part of it, according to several critics of this approach, has exactly to do with its lack of a clear analytical focus. While the meaning of transnationalism is often taken for granted, it may turn out to be far from obvious, as I will contend.

Most ways of defining migrant transnationalism seem prone to a conceptual dilemma (Lazar, 2011; Boccagni, 2012b). Indeed, as one attempt to define transnationalism, (s)he will risk getting trapped between two opposed and equally dissatisfying stances. If the option goes to a broad definition (as is often the case), this is likely to amount to little, if anything new under the sun. Evoking migrants' transnational ties and relationships, without providing a framework for operationalizing (or anyway empirically discriminating) them, is basically an exercise in commonsense. It does not bring any distinctive analytical value; it is of little help for empirical research; it can be hailed, at most, as a reminder about the need to approach immigrants also, and simultaneously, as emigrants - i.e. as citizens of their country of origin and members of its society, both of which may have significant stakes in their life trajectories abroad.

Importantly, the core assumption of the transnational perspective is much more radical than a simple recognition of the importance of home societies to migrants' lives (and vice versa). Its key argument has rather to do with the unprecedented scope for significant interactions to occur and persist over time between here and there, producing meaningful effects on both sides. While the coexistence of an immigrant and emigrant status (with its attendant structure of opportunities) is relatively straightforward, the possibility to replace physical absence with social presence, via transnational migration, is much less obvious - and may be aptly regarded as the most innovative, if contentious fruit of a transnational optic (Carling et al., 2012).

On the other hand, stricter definitions (along the lines, for instance, of Portes et al., 1999 and Guarnizo et al., 2003), are likely to highlight that transnational migrants stricto sensu are just a tiny part of the whole. They also risk hypostatizing transnationalism as a monolithic entity or property - something that is or is not. This remarkably under-

2 Even a simple list of the key works on migrant transnationalism would require an article in itself. Major reviews have however been provided, amongst others, by Kivisto (2001); Levitt and Jaworsky (2007); Vertovec (2009). 
estimates its huge scope for variation in time and space, depending on migration (and migrants') trajectories and on the broader structures of opportunities available. An understanding of the transnational as a potential attribute, along a continuum with different degrees of intensity, frequency, extensity and durability, is what would be missing here.

As of now, one may even focus on the transnational as an adjective (indeed, an attribute) in itself, leaving apart the cumbersome notion of transnationalism - whose final ism still betrays a teleological expectation in some of its early supporters. Nevertheless, what this means is not univocal, nor always self-evident. Now and then, all across migration studies, transnational tends to be used as a mere synonym of (if more trendy than) international. The increasing use of half-synonyms such as cross-border, at/from a distance, from afar, etc. is possibly a way of coping with this ambivalence. A possible way ahead, which reflects the work already done by many authors in the field, lies in positing the following pre-condition for a bi- (or multi-) sited phenomenon to qualify as transnational: the development of socially significant and empirically detectable interactions between its different national settings, whereby migrants prove able to affect nonmigrants' lives despite being physically distant from them - and, potentially at least, vice versa (Boccagni, 2010; 2012a).

Empirically speaking, while migrant transnationalism can also be appreciated in the light of the cross-border social formations that substantiate it, the focus of this article will be on a micro, interpersonal level. This involves the forms of transnational participation of individual or collective actors, whatever the macro-infrastructures they produce (Morawska, 2003). The ties and activities that connect migrants with their home societies - along with their mutual attachments and affiliations - could be classified, in this agency-centered optic, according to their distinctive empirical contents (table 1). An analytical distinction is proposed, here, between attitudes or identifications vs. relationships and practices, on the one hand; between three conventional realms of social action an economic, a political and a socio-cultural one (cf. Portes et al., 1999) -, on the other. A major contention underlying this framework is that migrants' persisting attachments to their home countries may be substantiated also (or even only) in their individual and group identifications, no less than in externally observable social practices (Levitt et al., 2003; Snel et al., 2006).

While table 1 provides a map of the key areas of research on migrants' transnational living, and on their faceted relationships with home societies, significant room still exists for further elaboration. This holds both at a theoretical and at an empirical level - even more so in a comparative perspective and on receiving contexts other than the US (Waldinger, 2011). Moving along the first of these lines, I will argue for the need to expand on the distinctive analytical value of the "conceptual kit" of transnational studies, vis-à-vis the pre-existing mainstream lexicon (section 2). I will also highlight the need to situate migrants' transnational ties and relationships in their individual and family life trajectories - thus turning a "transnationalism of everyday life" perspective (Boccagni, 2012a) into a helpful optic for fieldwork research (section 3). Before drawing some sociological conclusion, I will also sketch a few notes on the role of a researcher's reflexivity in approaching migrant transnational practices (section 4). 
Table 1: A typology of the key forms of immigrant transnationalism, by analytical level and domain of social action

\begin{tabular}{|c|c|c|c|}
\hline & Economic domain & Political domain & $\begin{array}{c}\text { Sociocultural } \\
\text { domain }\end{array}$ \\
\hline $\begin{array}{l}\text { (1.) Identitarian- } \\
\text { attitudinal } \\
\text { level ('bifocal' } \\
\text { identifications and } \\
\text { senses of belonging, } \\
\text { pointing both to the } \\
\text { home and the host } \\
\text { society) }\end{array}$ & $\begin{array}{l}\text { - Predilection for } \\
\text { consuming goods } \\
\text { from the country of } \\
\text { origin }\end{array}$ & $\begin{array}{l}\text { - Patriotism, } \\
\text { long-distance } \\
\text { nationalism } \\
\text { - Attachment to } \\
\text { the motherland's } \\
\text { citizenship } \\
\text { - Affiliation to } \\
\text { the motherland's } \\
\text { political parties or } \\
\text { institutions } \\
\text { - Interest to } \\
\text { follow and keep } \\
\text { systematically } \\
\text { abreast of the } \\
\text { current events in } \\
\text { the motherland }\end{array}$ & $\begin{array}{l}\text { - Long-term } \\
\text { nostalgia } \\
\text { - Prevailing social } \\
\text { identification with } \\
\text { co-nationals abroad } \\
\text { or in the } \\
\text { motherland } \\
\text { - Self-identification } \\
\text { with the culture, art, } \\
\text { folklore, etc. of the } \\
\text { motherland } \\
\text { - 'Myth of return' }\end{array}$ \\
\hline $\begin{array}{l}\text { (2.) Relational } \\
\text {-behavioral level } \\
\text { (social relationships } \\
\text { persisting at a } \\
\text { distance; social } \\
\text { practices creating } \\
\text { systematic } \\
\text { connections } \\
\text { between origin and } \\
\text { destination countries) }\end{array}$ & $\begin{array}{l}\text { - Sending } \\
\text { remittances (mostly } \\
\text { to family members } \\
\text { left behind) } \\
\text { - Sending gifts or } \\
\text { money supporting } \\
\text { the motherland } \\
\text { (and/or the origin } \\
\text { community) } \\
\text { - Investments } \\
\text { (houses, estates, } \\
\text { small businesses, } \\
\text { etc.) in the } \\
\text { motherland } \\
\text { - Ethnic enterprises } \\
\text { promoting } \\
\text { exchanges with the } \\
\text { motherland } \\
\text { - Circular } \\
\text { international labour } \\
\text { migration }\end{array}$ & $\begin{array}{l}\text { - Motherland- } \\
\text { related } \\
\text { political activism } \\
\text { (enacted 'here' or } \\
\text { 'there') } \\
\text { - Distance voting } \\
\text { - Exercise of dual } \\
\text { citizenship }\end{array}$ & $\begin{array}{l}\text { - Visits and/ } \\
\text { or systematic } \\
\text { communication } \\
\text { at a distance with } \\
\text { kin and friends left } \\
\text { behind } \\
\text { - Participation } \\
\text { in or support to } \\
\text { civic, recreational, } \\
\text { religious or } \\
\text { solidarity initiatives } \\
\text { or organizations - } \\
\text { either in the } \\
\text { motherland or } \\
\text { promoted abroad, } \\
\text { but addressed to the } \\
\text { motherland }\end{array}$ \\
\hline
\end{tabular}

Source: Boccagni, 2012b: 297. 


\section{FRAMING MIGRANT CROSS-BORDER INTERACTIONS: TOOLS, CONCEPTS, METAPHORS}

A reflection is worth making, to begin with, on the relationships between some notions that are typically associated to transnationalism and the preexisting conceptual apparatus of migration studies. Migrants' ties with their home countries, while relatively understudied before the transnational turn, had already been conceptualized to some extent in different terms, such as diaspora(s) or networks. What is, compared with them, the added value of the category of transnational, and of the words - such as space or field that are usually matched with it? In the face of this question I will first provide a brief outline of the earlier keywords, to be then revisited vis-à-vis the notion of transnational.

\section{Naming the Transnational, Prior to Transnationalism? Some Notes on Diasporas and Migrant Networks}

A helpful distinction can be made, in the first place, between the conceptual bases of migrant transnationalism and those of the pre-existing notion of diaspora. The latter applies only, properly speaking, to a possible historical development of a widespread emigrant flow. In a rigorous sense, the concept of diaspora stands for an ethnic, national or religious group that has been for long dispersed in a variety of countries, after a massive (and often forced) emigration process. Diasporas' groups also tend to occupy a marginal position in the countries of destination. Along with a strong collective identification, they share a pervasive expectation for return to their homeland - were it even in an undefined future (see, amongst others, Clifford, 1997; Levitt, 2001; Brubaker, 2005). Strictly speaking, as Bauböck has pointed out, a diaspora is by no means reducible to a simple aggregate of co-nationals living abroad:

“'Diaspora'... is a less precise and more ideologically charged concept than 'expatriates.' The notion of diaspora should be reserved for a specific type of collective identity that involves a strong sense of shared commitment to an external homeland and a narrative about a future return to this homeland. A diasporas' identity can be sustained across generations and across borders among geographically dispersed groups." (Bauböck, 2007: 2399)

Central to the notion of diaspora is, in the first place, the intergenerational reach of a collective identity that does not rely any more on communal territorial belonging (which highlights its distinctiveness vis-à-vis a broader notion of ethnic minority); secondly, a strategic orientation to mobilize such identity - that is, quoting again Bauböck (2007: 2399), "a specific project of identity formation and political mobilization that may be successful in some cases but will fail in many others".

Ironically, however, the literature on "diasporas" of any kind and meaning has been growing much faster than the transnationalism-related one in the last few years. Diaspora itself has arguably turned into a new and more appealing by-word to the eyes of policy-makers, NGOs, funding agencies, and possibly even to migrant associations. The increasing development of external citizenship policies (e.g. Østergaard-Nielsen, 2003; 
Barry, 2006) - up to special "diaspora-building" strategies (Gamlen, 2008) - has also contributed to the renewed public salience of this notion.

In more theoretically rigorous terms, though, the relationship between these two categories has been extensively discussed (e.g. Bauböck \& Faist, 2010). What can be added here is that transnational migration studies have also developed an agential focus on the micro-level of analysis, which is almost absent in diaspora studies. The former, in other words also address the multiplicity of simultaneous and interactive ties between individual migrants (and their groups) and their relevant "interlocutors" in the homeland or elsewhere. The structural development of migrant transnational participation and the range of meanings and expectations associated to it are no less important - in a transnational optic - than the aggregate output of their cross-border ties. If, and as such ties result in a non-territorialized infrastructure of connections between homeland and expatriates - and of course, among migrants themselves -, the preconditions exist for an "actually existing" diaspora to reproduce itself over generations, on a national, religious or ethnic basis (Levitt, 2001).

Another cognate notion, which had already wide currency before the transnational approach was introduced, is that of migrant network, ${ }^{3}$ as a conceptual tool that mediates between macro/structural and micro/agency theories of migration. The very start of a migration flow, and even more its development, can be understood as an extended process of network-building between migrants and non-migrants, with a high potential for self-reproduction (Boyd, 1989; Massey et al., 1993). Although these general remarks cannot do justice to the complex role of social networks in migration, a good case can be made for presenting the transnational perspective as an "extension" of the network approach (Ambrosini, 2008). Following this argument, migrant networks, apart from circulating resources in both directions, can assume an infrastructural density, and exert a systemic impact, which require further conceptual tools. Primary among them is the notion of social field - something that Glick Schiller (2003) regards as more inclusive than a mere network. ${ }^{4}$ Whatever the difference, one can reasonably conclude that the transnational optic has shed light on a specific arrangement of migrant networks in terms of range, intensity and structuration.

3 Following the famous definition of Massey et al. (1993: 448), a migrant network - as "a form of social capital" - is a "set of interpersonal ties that connect migrants, former migrants and nonmigrants in origin and destination areas through ties of kinship, friendship, and shared community origin".

4 More specifically, in the author's words, "networks are generally understood to be chains of social relationships that extend from a single individual. Network analysis is egocentric; it directs our attention to the density and types of relationships of a specific individual. In contrast, the analysis of social field is socio-centric. We focus on alterations in social actions, ideas and values as people are linked together by means of multiple interlocking networks" (Glick-Schiller, 2003) (I will return below to the strictly related notion of transnational social field).

REMI 2012 (28) 1 pp. 33-50 


\section{Some Categories for Embodying the Transnational: Spaces, Fields... and Beyond}

As I approach, now, the conceptual toolkit that is specific to transnational studies, two notions at least deserve an extended presentation: (transnational) social space and field. Although extensive literature exists on both, some remarks can be helpful in highlighting - and in some respects, problematizing - their distinctive meaning vis-à-vis the concepts discussed above. How is it that these notions can illuminate some facets of migrants' life experience, under conditions of transnational social living?

The notion of transnational social space, specifically elaborated by Thomas Faist, provides a sort of a bridge between migration and globalization studies. This well-known term indicates, in quite abstract and general terms,

"Combinations of social and symbolic ties, positions in networks and organizations and networks of organizations that can be found in at least two geographically and internationally distinct places [...]. Transnational social spaces are constituted by the various forms of resources or capital of spatially mobile and immobile persons, on the one hand, and the regulations imposed by nation-states and various other opportunities and constraints, on the other [...]. Transnational social spaces are characterized by triadic relationships between groups and institutions in the host state, the sending state... and the minority group - migrants and/or refugee groups, or ethnic minorities." (Faist, 1998: 216-217)

Such "spaces", to be understood both as physical and symbolic ones encompass at least two geographically and politically distinct places. While being based on strong and systematic connections between migrants and their homelands, they are still constrained by the policies and regulations of the nation states within which they develop. Following the argument of Faist (1998: 220) again, transnational social spaces should be analytically distinguished, in the light of their degree of institutionalization, between three analytical types: $i$. Kinship- and community-based ties and exchanges, which typically rely on strong bases of mutual solidarity and trust; ii. Circuits, where a "constant circulation of goods, people and information" occurs at a cross-border level, mediated by instrumental exchanges between the actors involved; iii. Communities, which would entail - to be conceptualized as such on a transnational basis - the existence of a collective identification, and of solidarity ties, on a broader scale than a territorially defined one.

Remarkably, the notion of transnational communities had a prominent position in the earlier academic discourse on transnational migration (e.g. Rouse, 1992; Portes, 1996; Kearney, 2000). Its salience has clearly lessened, however, in the last decade. This suggests an increasing awareness of the selective, if increasing scope for applying this notion as an analytical tool - rather than as an evocative metaphor. Broadly speaking, some elite migrant networks (e.g. transnational entrepreneurs, political activists, highly skilled workers, members of religious congregations, etc.) have a clear potential to turn into transnational communities - based on the enactment of "dense and strong social and symbolic ties over time and across space" (Faist, 1998: 221). That said, most transnational connections - even those that involve a multiplicity of actors - are just too loose and unsystematic to qualify as a community of any kind. 
Less ambitious and ultimately more successful has been the notion of transnational social field. ${ }^{5}$ In many respects, this concept seems more suitable to represent crossborder participation as a multi-dimensional and multi-sited process; one that needs not result in strong collective identifications and still requires better understanding, as for its social distribution and intergenerational persistence. Following the most popular definition, a transnational social field could be framed like a cumulative aggregate of migrant cross-border practices, whereby material and immaterial resources are circulated, negotiated and (possibly) transformed between "here" and "there":

"[A social field is, PB] a set of multiple interlocking networks of social relationships through which ideas, practices, and resources are unequally exchanged, organized, and transformed. [...] [In a transnational perspective, this entails a, $P B]$ focus on the intersection between the networks of those who have migrated and those who have stayed in place [...] [This also enables, PB] comparisons between the experiences of migrants and those who are only indirectly influenced by ideas, objects, and information flowing across borders." (Levitt \& Glick Schiller, 2004:

1009-1012)

As far as migrants are concerned, being situated in a transnational social field means assuming, in a more or less intentional and cognizant way, societal roles and functions involving both their home and host societies. Moreover, the notion of field helpfully circumscribes migrant transnational engagement in time and space, against the ever fashionable tendency to portray it as a disembedded and "free-floating" matter. The emphasis is put, instead, on the outcome of several multi-local exchanges. Such transactions, while involving both migrants and non-migrants, do not necessarily rely on a communal social milieu - be it even a highly symbolic one - such as the one implicit in the notion of community.

Having said this, it is still unclear by which measure we should assess migrants' embeddings in a transnational social field - and, for that matter, what the criteria are for delimiting its boundaries (Boccagni, 2012b). As a result, developing empirical analyses of the relationships of power that occurs within a given transnational social field and shape its shifting contours is still an unaccomplished task. Much the same can be said, after all, about the distinctive representations, emotions and perceptions - in a word, the belonging - that a transnational social field elicits in those who are socially involved in it as movers or stayers (Viruell-Fuentes, 2006).

There is still another reason why, in my opinion, the notion of transnational social field - while promising - requires further elaboration. While investigating upon it in my fieldwork (Boccagni, 2010) on Ecuadorian migration to Italy - a recent, first-generation immigrant flow across a large distance -, I found that the notion of a field, even only as a metaphor, overestimated what I was observing. Within a migration system still unde-

5 This notion builds on a variety of antecedents in social theory - to which, again, I cannot do justice here. The most remarkable of them, however, seem to be the Manchester school of social anthropology, in the first place; secondly, the theoretical elaboration of Bourdieu (1993). The French sociologist designated as "social field" a constrained set of social positions, whose organization mirrors a given set of social interests, regulated by the evolving power relationships between the actors involved in it. 
veloped and with limited cross-border infrastructures, migrant transnational participation tended to assume a simply dyadic shape, limited to the connections between transnational parents and their kin left behind. Such grassroots ties were however, for several reasons, much more intermittent, rarified and "privatized", so to speak, than the idea of a field would have suggested. To be sure, they had a remarkable impact at an aggregate level witness to this the figures of remittances, transnational communication, return visits, etc. Yet, such "aggregate" looked like a chaotic juxtaposition of individual trajectories that, despite their striking commonalities, had little to say to each other. By no means was it constructed, or even only felt by individual immigrants as a communal field for transnational action.

While all Ecuadorian migrants I met had a strong nostalgia of (and a degree of interest in) Ecuador, what stood in-between them and their homeland seemed to be only, in their eyes, an increasing distance - which their individual initiatives would attempt at filling somehow. That the sum of these micro-initiatives of distance-filling was something substantial was clear to money-transfer agencies, to some NGOs, even to the emerging efforts at diaspora-building of the Ecuadorian government. It was however far from a field of communal interaction between immigrants, in a sort of de-territorialized public arena. More than a transnational field, it would have likely elicited the metaphor of a transnational void - if ever they had bothered to reflect upon it.

\section{MAKING BIOGRAPHICAL SENSE OF TRANSNATIONAL TIES: THE MIGRANT-LEFT BEHIND NEXUS OVER THE LIFE COURSE}

Migrant transnationalism, in an everyday life perspective, is basically a matter of personal ties - that is, of close relationships being cultivated and negotiated from a distance in a number of ways (i.e. via remittances, transnational communication, return visits, etc.). The core theme for research, in other words, lies in the social consequences of the migrantleft behind nexus: how, why, and producing which effects movers and stayers enact their mutual, asymmetrical and often conflicting bonds. There is solid ground to argue, as a matter of fact, that the bulk of migrants' transnational engagement is not addressed to their home country as a whole. It rather tends to involve a limited and selected group of significant others still living there (Waldinger \& Fitzgerald 2004; Waldinger, 2011). In terms of day-to-day social practices, all other transnational spill-overs (i.e. collective remittances, support to party politics or hometown associations, ethnic entrepreneurship, etc.) are far less frequent and intense. This is not to deny, of course, the societal significance they often gain at an aggregate level.

Once reframed along these lines, migrant cross-border ties are by no means fixed entities or properties. Quite the contrary: they emerge as selective and dynamic attributes, with a variable aggregate "potential" (Carling, 2008). Their effective activation should be understood as a process that is dually situated: in space, within cross-border relational infrastructures that rely on two (or more) physical settings, but also on the resources being circulated in-between; in time, as such ties are fluid and mutable, very much like migrant evolving biographies. 
Indeed, a relatively neglected trigger of migrants' transnational involvement is their position in the life course and, at a macro level, the stage of a migration cycle they belong to. Since labor migration is typically underpinned by family-based ties and obligations, especially in its early stages, it is no surprise that cross-border ties tend to mirror - as for prevalence, intensity and attributed meanings - the biographical transitions in migrants' life experience (Kobayashi \& Preston, 2007). It is critical, then, to make sense of such ties in the broader frame of their life course. The latter should be understood as a more or less standardized collective "sequence of stages or status-configurations and transitions in life which are culturally and institutionally framed", in any given society, "from birth to death" (Heinz \& Kruger, 2001: 33). Within this frame, migration marks a major disjuncture in the life experience of those involved as movers and even, to some extent, as stayers. It inherently undermines any representation of the life course as a natural and routinized social order. It also enlarges, in practical terms, the room for the "claims" - and in many ways, the needs - "for individualization and biographization" (Kohli, 2007: 257).

Given these premises, one may wonder if, and how, migrants' transnational ties contribute to recreate some "life time continuity", hence some "life time security and predictability" (Kohli, cit.: 256), to bridge the gap between their past and present life experiences. The answer, in my opinion, is positive - yet, ambivalent.

Interestingly, migration-related transitions in the life course can also be understood in the light of the variety of transnational ties activated by those involved. Engaging with the homeland, and/or with those left behind, can be more or less viable, useful and effective, depending also on a migrant's family condition abroad, and on the shared life projects of its members. It is not irrelevant, for instance, whether an immigrant is alone or lives together with its kin; whether some "significant other" is still domiciled in the homeland or not; whether there is a strong expectation for return or not; and so forth. In each of these respects, against the identity and relational disruptions that migrants are likely to face, transnational ties are a mixed resource. They can obviously act as a source of identification, of perceived life continuity, even of social protection. A degree of connectedness with non-migrants does counter the disorientation and the loss of social capital that are typically associated to immigration. Apart from substantiating migrants' interdependence with left-behinds, however, transnational ties also carry a range of tensions, unmet expectations, moral and affective burdens. All of the latter emerge, for instance, in the changing patterns of negotiating and managing remittances.

By way of example, again, I will explore this ambivalence through some case studies I did on Ecuadorian migrants in Italy - part of an immigrant flow marked first by a strong prevalence of young and middle-aged women, attracted by easily accessible jobs in the care sector; then, by a gradual realignment along gender and generational lines, enabled by family reunification (Boccagni, 2010; Boccagni and Lagomarsino, 2011).

To repeat: during my fieldwork among Ecuadorians in Italy and their non-migrant counterparts in Ecuador, I found the strongest investment in transnational ties among female early migrants - in fact, transnational mothers who had to negotiate strained intergenerational and couple relationships from afar. In general terms, however, the home-ward ties they did cultivate via remittances, phone calls, etc. tended to lose some salience, as 
they proceeded with reunifications. This was also the case, judging from my fieldwork, for migrants' interest in the everyday life of their country (concerning politics, economics, etc.). In a way, the longer my Ecuadorian informants had been abroad, the higher the likelihood that "Ecuador" was for them a source of nostalgia and (good) memoirs, rather than an actually existing country - indeed, the sole repository of their citizen status.

Feeling Ecuadorian, on the other hand, was a striking commonality among nearly all the first-generation immigrants I met. Yet, only some of them - especially transnational parents, prior to family reunion - did match this national identification with a systematic set of cross-border social practices. Transnational engagement was sporadic, instead, for adult immigrants who had already reunited the bulk of their family members, and even more so for the second (and 1.5) generation youth. Especially for the latter, ironically, claiming and enacting "Ecuadorianness" had to do with their symbolic ethnicity abroad (in terms of patterns of sociability, consumption, leisure, life styles, etc.), rather than reflecting any sustained connection with Ecuador as a real place.

In a way, a strong form of ascriptive transnationalism, based on affective and moral interdependencies with close kin, was prevalent among the former (i.e. transnational parents). A more malleable and intermittent form of elective transnationalism, related to migrants' own options and interests (including expectations to return), was instead the rule among the latter ${ }^{6}$ - indeed, for almost all migrants who were no more strictly involved in a transnational family regime. ${ }^{7}$ The point, however, is that these categories did not stand for distinctive social profiles. They just mirrored the correlation between migrants' attitudes toward their home societies (and the attendant social practices), and the phase of their biographies (and, at a macro level, of their migration cycle).

Having said this, a gradual decrease in transnational involvement was just a broad rule, with remarkable exceptions. As long as migrants' belonging was mainly addressed to their homeland - as it typically was, in the first generation at least -, a deep-rooted, if often tacit expectation existed, whereby they were still to share with non-migrants something of their supposed wealth. Remittances, more broadly, were embedded in a regime of affective and moral responsibilities that tended to be more durable than most transnational practices stricto sensu. Demands for support related, for instance, to some philanthropic initiative, or to some urgent health need were still addressed to migrants even as they had become long-resident abroad.

\section{AT THE END OF THE DAY: ISN'T IT (ALSO) A MATTER OF SCHOLAR REFLEXIVITY?}

Summing up, there is no denying that a range of transnational attributes and ties can be empirically detected in most migration flows, with mutable degrees of intensity, prevalence, frequency, persistency - in other words, with strong variations in social and

6 A similar distinction, in terms of identity-based vs. resource-based transnationalism, has recently been developed by Tamaki (2011).

7 On the other hand, those who had turned elective transnationalism into an ordinary practice political activists, transnational entrepreneurs, etc. - were just a tiny minority. 
societal significance. Yet, given the typically situated, relational and biographically-relevant nature of transnational attributes at a micro-level, too broad conclusions on the matter are hardly of any help (or interest).

There is however a point which, in a field of study so far dominated by qualitative research, has been curiously neglected. What is the role, one may wonder, of a researcher's personal values, inclinations and aspirations, in the changing contours of the transnational perspective (s)he contributes to? This is not, generally speaking, a role of simply neutral observation - if ever that were achievable, or even only desirable, in social sciences. Yet, reflection on this role and on its reverberations has remained quite marginal in the transnationalism debate, apart from the usual (and in many ways justified) criticisms of the tendency to "sample on the dependent variable" - i.e. to preselect only the cases more favorable to one's own argument. This is a clear sign, however, of a systematic need for more reflexivity.

Once a more reflexive attitude is assumed, a (self-) critical concern can emerge about the risk of reducing transnationalism to one's own projections. The point could be roughly articulated as follows: in principle, scholars with some cosmopolitan background (or even only aspiration) may well be fascinated, admittedly or not, by the idea of the transnational as such. There is no inherent reason, however, why the bulk of labour migrants should share their enthusiasm. Put differently, and less provocatively: transnational ties could be helpfully understood as an instrumental option on which migrants can rely, if so they wish (or indeed: if they have to), depending on their own biographical agendas (and constraints). While such ties may be a mixed fruit of desire, interest, need and obligation, there is nothing necessarily "good", progressive or desirable per se in cultivating them. Teleological, even morally-oriented understandings, in a more or less disguised fashion, have still a currency, here, that deserves to be questioned.

Claiming more room for reflexivity also leads me to cope with an equally important (and neglected) facet of the personal significance of transnational ties - to migrants, and to their stay-behind counterparts. There is a basic distinction to be made, here, along the divide of an etic vs. emic understanding of a given social phenomenon. It is by no means irrelevant that the category of transnational, while increasingly popular among academics, is likely to say little - if anything - to labour migrants themselves (unless, possibly, to a highly selected minority of political activists or entrepreneurs). The rank and file of them tend rather to frame their home-addressed engagement in terms of nostalgia, affection, obligations, loyalty, hope for return and thus forth.

Put otherwise, the transnational, even when empirical substantiated, is still only a structural feature of a kind of social relationships - on which flesh needs then to be put on bases more sociologically relevant, and subjectively meaningful, than an abstract category. Less than with "things out there", at the end of the day, the transnational perspective has to do with a peculiar societal arrangement of such things - one marked by a lack of physical co-presence and by a variety of attempts to redress it, more or less effectively, through social interactions from afar. 


\section{CONCLUSIONS: SOME HINTS FOR A SOCIOLOGICAL WAY AHEAD}

All over the course of this mapping exercise, it was my contention that, even after two decades of research, the theoretical debate on migrant transnationalism is far from exhausted; indeed, it still deserves further elaboration. This holds in a number of respects, including those I have attempted to revisit in this article:

- First, the need for definitions authentically conducive to empirical research, which is not to deny their limitations, or their connection with one's selective interests (in my case, the everyday micro-dimension of transnational practices, to be inferred from the migrant-left behind nexus);

- Second, the continuities of the transnational lexicon with the mainstream conceptual tools of migration studies, which are arguably stronger that many proponents of this approach would admit;

- Third, the critical embeddings of migrants' cross-border participation in the evolving trajectories of their life course, which is not incompatible (indeed: it goes hand in hand) with the range of other factors that account for their transnational practices;

- Last, the lack of reflexivity that surprisingly emerges from many methodological accounts of transnationalism, and the need to appreciate the distinction between the transnational as a category for academics (as it mostly is), and as a term that makes real sense to migrants themselves.

All this being said, revisiting migrant transnationalism still elicits, in a sociological optic, another issue that requires better elaboration: the scope for maintaining and negotiating proximity, as a perceptive/sensorial matter and as a functional condition for social action, once a given social interaction is made independent from physical co-presence (Urry, 2002). All in all, this theme is still under-researched. Even so, it is a general feeling that some visual and even physical proximity, on a periodical basis at least, remains an important requirement for pursuing communal interests of any kind, among social actors detached from each other - even more if the latter have strong mutual affective ties. Virtual communication, while obviously fundamental and more and more pervasive, does not seem (yet) enough - generally speaking - to redress an extended physical detachment in every respect.

Such an issue is now being addressed in the interdisciplinary domain of mobility studies (e.g. Adey, 2010). It remains remarkably neglected, though, by most sociologists of migration. It is exactly in the past sociological tradition, however, that we can trace a seminal insight on the crucial relevance of a proximate visual contact - hence of co-presence or corporeal proximity - to the development of sustained and significant social relationships.

In a nutshell, as Urry (2002: 259) puts it, it is only "eye contact" that fully "enables the establishment of intimacy and trust, as well as insincerity and fear, power and control". This point has been inspired by an illuminating passage of Georg Simmel's Excursus on the sociology of the senses (1908): 
"Among the individual sensory organs, the eye is destined for a completely unique sociological achievement: the connection and interaction of individuals that lies in the act of individuals looking at one another. This is perhaps the most direct and the purest interaction that exists. [...] Even the spoken and heard word has an objective meaning, which, if need be, could be transmitted in a different way. The extremely lively interaction, however, into which the look from one eye to another weaves people together, does not crystallize in any objective structure, but rather the unity that it creates between them remains directly suspended in the event and in the function. And this connection is so strong and delicate that it can only be supported by the shortest line - the straight line between the eyes [...]. One reveals oneself in the look that receives the other into oneself; in the same act with which the human subject seeks to recognize its object, it surrenders itself to the object. One cannot take through the eye without at the same time giving. The eye reveals to the other the soul that he or she seeks to reveal...the most complete reciprocity in the entire sphere of human relationships is achieved here." (Frisby and Featherstone, 1997:

As one reads in the subtext, the German sociologist had good (if tacit) reasons to assume that a vis-à-vis setting - one which enabled the human eye to fully enact this mutual function - was almost a rule for social interactions. Over a century afterwards, as social disembeddedness is a much more widespread basis for interpersonal relations (migration being one of the factors accounting for this), Simmel's insight can be brought, and possibly problematized, a step forward. As human relationships are, more often than not, systematically disconnected from physically proximity, the scope for reproducing "a perfect reciprocity" in them still needs to be critically inquired. This is, I believe, a promising way ahead for a new and more sophisticated sociological approach to migrants' (indeed, to anybody's) transnational ties, identifications and relationships. 


\section{References}

ADEY Peter (2010) Mobility, London, Routledge, 288 p.

AMBROSINI Maurizio (2008) Un'altra globalizzazione: la sfida delle migrazioni transnazionali, Bologna, Il Mulino, $256 \mathrm{p}$.

BARRY Kim (2006) Home and away: The construction of citizenship in an emigration context, New York University Law Review, 81 (11), pp. 11-59.

BAUBÖCK Rainer (2007) Stakeholder citizenship and transnational political participation, Fordham Law Review, 75, pp. 2393-2447.

BAUBÖCK Rainer and FAIST Thomas (Eds.) (2010) Diaspora and Transnationalism, Amsterdam, Amsterdam University Press, $376 \mathrm{p}$.

BOCCAGNI Paolo (2012a) Rethinking transnational studies: transnational ties and the transnationalism of everyday life, European Journal of Social Theory, 15 (1), pp. 117-132.

BOCCAGNI Paolo (2012b) Even a transnational social field must have its boundaries. Methodological options, potentials and dilemmas for researching transnationalism, in Carlos Vargas-Silva Ed., Handbook of Research Methods in Migration, Cheltenham, Edward Elgar, pp. 295-318.

BOCCAGNI Paolo (2010) Private, public or both? On the scope and impact of transnationalism in immigrants' everyday lives, in Rainer Bauböck and Thomas Faist Eds, Diaspora and Transnationalism, Amsterdam, Amsterdam University Press, pp. 185-205.

BOCCAGNI Paolo e LAGOMARSINO Francesca (2011) Transnazionalismo e percorsi familiari: profili di genere e di generazione a confronto nell'immigrazione ecuadoriana, Studi di Sociologia, 49 (4).

BOURDIEU Pierre (1993) Some properties of fields, in Pierre Bourdieu, Sociology in question, London, Sage, pp. 72-77.

BOYD Monica (1989) Family and personal networks in international migration, International Migration Review, 23 (3), pp. 638-669.

BRUBAKER Rogers (2005) The "Diaspora" Diaspora, Ethnic and Racial Studies, 28 (1), pp. 1-19.

CARLING Jorgen (2008) Toward a Demography of Immigrant Communities and Their Transnational Potential, International Migration Review, 42 (2), pp. 449-475.

CARLING Jorgen et al. (2012) Central themes in the study of transnational parenthood, Journal of Ethnic and Migration Studies, 38 (2), pp. 191-217.

CLIFFORD James (1997) Routes. Travel and translation in the late twentieth century, Harvard, Harvard University Press, $412 \mathrm{p}$.

HEINZ Walter and KRUGER Helga (2001) Life course: Innovations and challenges for social research, Current Sociology, 49, pp. 29-45.

FAIST Thomas (1998) Transnational social spaces out of international migration, Archives Européennes de Sociologie, 39 (2), pp. 213-247.

FRISBY David and FEATHERSTONE Mike (Eds.) (1997) Simmel on culture. Selected writings, London, Sage, $320 \mathrm{p}$.

GAMLEN Alan (2008) The emigration state and the modern geopolitical imagination, Political Geography, 27 (8), pp. 840-856.

GLICK-SCHILLER Nina (2003) The centrality of ethnography in the study of transnational migration, in Nancy Foner Ed., American Arrivals, Santa Fé, School of American Research, pp. 99-128.

GUARNIZO Luis et al. (2003) Assimilation and transnationalism, American Journal of Sociology, 108 (6), pp. 1211-1248.

KEARNEY Michael (2000) Transnational Oaxacan Indigenous Identities, Identities, 7 (2), pp. 173-195.

KIVISTO Peter (2001) Theorizing Transnational Migration, Ethnic and Racial Studies, 24 (4), pp. 549-577. 
KOBAYASHI Audrey and PRESTON Valerie (2007) Transnationalism through the life course: Hong Kong immigrants in Canada, Asia Pacific Viewpoint, 48 (2), pp. 151-167.

KOHLI Martin (2007) The institutionalization of the life course: Looking back to look ahead, Research in Human Development, 4 (3-4), pp. 253-271.

LAZAR Andreea (2011) Transnational migration studies: Reframing sociological imagination and research, Journal of Comparative Research in Anthropology and Sociology, 2 (2), pp. 69-83.

LEVITT Peggy (2001) Transnational migration: Taking stock and future directions, Global Networks, 1 (3), pp. 195-216.

LEVITT Peggy et al. (2003) International perspectives on transnational migration: An introduction, International Migration Review, 37 (3), pp. 565-575.

LEVITT Peggy and GLICK-SCHILLER Nina (2004) Conceptualizing simultaneity: A transnational social field perspective on society, International Migration Review, 37 (3), pp. 1002-1039.

LEVITT Peggy and JAWORSKY Nadia B. (2007) Transnational migration studies: Past developments and trends, Annual Review of Sociology, 33, pp. 129-156.

MASSEY Douglas et al. (2003) Theories of international migration: A review and appraisal, Population and Development Review, 19 (3), pp. 431-466.

MORAWSKA Ewa (2003) Disciplinary agenda and analytic strategies of research on immigrant transnationalism, International Migration Review, 37 (3), pp. 611-640.

ØSTERGAARD-NIELSEN Eva (Ed.) (2003) International migration and sending countries, Houndmills, Palgrave, $256 \mathrm{p}$.

PORTES Alejandro (1996) Transnational communities: Their emergence and significance in the contemporary world system, in Roberto Patricio Korzeniewicz and William C. Smith Eds., Latin America in the world economy, Westport, Praeger.

PORTES Alejandro et al. (1999) The study of transnationalism: Pitfalls and promise of an emergent research field, Ethnic and Racial Studies, 22 (2), pp. 217-237.

ROUSE Roger (1992) Making sense of settlement: Class transformation, cultural struggle and transnationalism among Mexican migrants in the United States, Annals of the New York Academy of Sciences, 645 (1), pp. 25-52.

SNEL Erik et al. (2006) Transnational involvement and social integration, Global Networks, 6 (3), pp. 285-308.

TAMAKI Emi (2011) Transnational home engagement among Latino and Asian Americans: Resources and motivation, International Migration Review, 54 (1), pp. 148-173.

URRY John (2002) Mobility and Proximity, Sociology, 36 (2), pp. 255-274.

VERTOVEC Steven (2009) Transnationalism, London, Routledge, 216 p.

VIRUELL-FUENTES Edna (2006) "My Heart is Always There", Identities, 13 (3), pp. 335-362.

WALDINGER Roger (2011) Immigrant transnationalism, Sociopedia.isa, 2011, pp. 1-13.

WALDINGER Roger and FITZGERALD David (2004) Transnationalism in question, American Journal of Sociology, 109 (5), pp. 1177-1195. 


\title{
Revisiting the "Transnational" in Migration Studies: A Sociological Understanding
}

\author{
Paolo Boccagni
}

\begin{abstract}
After decades of extensive discussion and a number of empirical studies, the transnational approach is by now well established in migration studies. An open contraposition still exists however between its supporters and its detractors. As an attempt to move beyond it, this paper argues for the need to still elaborate on the sociological bases of this perspective in four respects: its underlying definitional issues, the nexus between its conceptual toolkit and that of "mainstream" migration studies, the need to situate transnational ties and relationships in migrant's life course, the reflexivity which is necessary to appreciate the transnational as a potential social attribute and as a social science category. The scope for enacting proximity in social relationships from afar is finally highlighted as a promising topic for a richer sociological investigation of transnational social living.
\end{abstract}

\section{Revisiter le « transnational» dans les études sur les migrations : une conception sociologique}

\author{
Paolo Boccagni
}

Après deux décennies de discussion intense et nombre d'études empiriques, l'approche transnationale occupe désormais une place de premier plan dans les études sur les migrations. Cependant il existe encore une controverse ouverte entre les thuriféraires et les détracteurs de cette approche. Pour tenter d'entrer plus avant dans ce débat, le présent article souligne la nécessité d'approfondir les bases sociologiques de la perspective transnationale sous quatre aspects : la question des définitions, le lien entre les outils conceptuels de l'approche transnationale et ceux des études sur les migrations au sens plus large, la nécessité de situer les liens et les relations transnationales à l'intérieur de la trajectoire de vie des migrants et la réflexion nécessaire pour comprendre le transnational soit comme un attribut social potentiel, soit comme une catégorie des sciences sociales. En conclusion, le processus de création de proximité dans les relations sociales à distance apparaît comme particulièrement intéressant pour enrichir les bases sociologiques des études sur la vie sociale transnationale.

\section{El «transnacional» en los estudios migratorios: sociológicos bases}

\section{Paolo Boccagni}

Después de dos décadas de debate académico, que se tradujo en una gran cantidad de estudios empíricos, la perspectiva transnacional está bien establecida en los estudios migratorios. Hay todavía una fuerte contraposición, sin embargo, entre sus partidarios y sus críticos. Para intentar de innovar este debate, el presente artículo subraya la necesidad de profundizar aún más las bases sociológicas de esta perspectiva, en cuatro aspectos: las maneras de definir el «transnacional»; el nexo entre los conceptos típicos de esta perspectiva y los de estudios migratorios en general; la necesidad de apreciar la importancia del curso de la vida, para los lazos y las relaciones transnacionales de los migrantes; la reflexividad que sirve para entender el transnacional como atributo social potencial y como categoría de las ciencias sociales. Al final, se argumenta que la posibilidad de «actuar proximidad» en las relaciones sociales a la distancia es un asunto de especial interés para el futuro desarrollo de las investigaciones sobre el «vivir transnacional» de los migrantes. 


\section{Il «transnazionale» nello studio delle migrazioni: una rivisitazione sociologica \\ Paolo Boccagni}

Dopo due decenni di dibattito serrato, e dopo moltissimi studi di campo, l'approccio transnazionale occupa ormai una posizione di primo piano negli studi migratori. C'è ancora una aperta contrapposizione, nondimeno, tra i fautori e i critici di questo approccio. Nel tentativo di muovere al di là di questa contrapposizione, il presente articolo sottolinea l'esigenza di approfondire ulteriormente le basi sociologiche della prospettiva transnazionale, sotto quattro aspetti: le questioni definitorie ad esso collegate; il legame tra il suo apparato concettuale e quello più generale degli studi sulle migrazioni; l'esigenza di situare i legami e le relazioni transnazionali entro il corso di vita dei migranti; la riflessività necessaria per comprendere il "transnazionale" sia come attributo sociale potenziale, sia come categoria delle scienze sociali. Nelle conclusioni, i processi di "realizzazione della prossimità" nelle relazioni sociali a distanza sono individuati come tema di particolare interesse per arricchire le basi sociologiche degli studi sulla vita sociale transnazionale. 